\title{
The Mechanism of Appearance of Immunoglobulin A in Nasal Secretions in Man*
}

\author{
William T. Butler, $\ddagger$ Roger D. Rossen, and Thomas A. Waldmann \\ (From the Laboratory of Clinical Investigation, National Institute of Allergy and Infectious \\ Disease, the Metabolism Branch, National Cancer Institute, National Institutes of \\ Health, Bethesda, Maryland and the Department of Microbiology, Baylor \\ University College of Medicine, Houston, Texas)
}

\begin{abstract}
Experiments were done to investigate mechanisms of appearance of both $7 \mathrm{~S}$ and $11 \mathrm{~S} \mathrm{IgA}$ in nasal secretions. Three IgA preparations, (a) $11 \mathrm{~S}$ IgA from nasal secretions, (b) $7 \mathrm{~S}$ IgA from homologous serum, and (c) $7 \mathrm{~S}$ IgA from autologous serum, were isolated, labeled, and injected intravenously into volunteers. The rate of disappearance from plasma and the extent and nature of their appearance in nasal secretions were examined in detail. After intravenous injection, $11 \mathrm{~S}$ IgA from nasal secretions disappeared rapidly from plasma. However, only negligible amounts of $11 \mathrm{~S} \operatorname{IgA}$ were detected in nasal secretion, which suggested that rapid selective secretion of circulating $11 \mathrm{~S}$ IgA does not occur as a mechanism of IgA accumulation in nasal secretions. Both the homologous and autologous $7 \mathrm{~S}$ IgA preparations disappeared from plasma at a normal rate, and both appeared in nasal secretions unchanged in sedimentation behavior. The specific activity of IgA in nasal secretions, when related to the total IgA concentration, was about 30-fold less than that in serum. When related to only the $7 \mathrm{~S}$ IgA concentration of nasal secretions, the specific activity was about one-half that of serum. These studies are consistent with the following hypotheses: (a) circulating $7 \mathrm{~S} \operatorname{IgA}$ is a source of part of the $7 \mathrm{~S} \operatorname{IgA}$ found in nasal secretions. The remainder of the nasal secretion $7 \mathrm{~S}$ IgA may be synthesized locally in the tissues of the upper respiratory tract; (b) $11 \mathrm{~S} \operatorname{IgA}$ in nasal secretions is not assembled from serum $7 \mathrm{~S} \operatorname{IgA}$ components; and (c) $11 \mathrm{~S} \operatorname{IgA}$ in nasal secretions is synthesized de novo in the tissues of the upper respiratory tract.
\end{abstract}

\section{Introduction}

Immunoglobulin A ( $\operatorname{Ig} \mathrm{A})$ is the most abundant protein in nasal secretions, and it accounts for up to one-half of the total protein present $(1-4)$. Over four-fifths of this IgA has been shown to be different from the IgA present in serum in that it has higher molecular weight, predominantly $11 \mathrm{~S}$ sedimentation behavior, and the presence of unique antigenic determinants (5).

Although nasal secretions contain small amounts of IgG, the major serum immunoglobulin compo-

\footnotetext{
* Received for publication 19 May 1967 and in revised form 10 August 1967.

$¥$ Address requests for reprints to Dr. William $T$. Butler, Baylor University College of Medicine, Texas Medical Center, Houston, Tex. 77025.
}

nent, antibody activity has been most closely associated with $\operatorname{IgA}(1,6,7)$. The presence in nasal secretions of IgA-associated antibody directed against certain respiratory viruses has correlated with protection from infection after challenge with homologous strains of virus $(8,9)$. The mechanism of appearance of such antibody in nasal secretions is unknown, and it has not been established whether $\operatorname{IgA}$ is synthesized de novo in the tissues lining the nasal membranes or whether these tissues transfer and possibly modify IgA from plasma.

The present experiments were designed to determine whether any portion of the $\operatorname{IgA}$ in the plasma pool is transferred into nasal secretions, and if so, whether any physicochemical alteration 
of the IgA molecule occurs during its transfer. Three preparations of IgA were radiolabeled and injected intravenously into volunteers, and the rate, extent, and nature of their appearance in nasal secretions were examined in detail.

\section{Methods}

\section{Volunteers}

Subjects were 20 normal adult males from federal correctional institutions (10) admitted to the Clinical Center, National Institute of Allergy and Infectious Diseases. 14 of these volunteers were used to obtain a large pool of nasal secretion $\operatorname{IgA}$, and the remaining 6 were used for the subsequent isotopic infusion studies. An additional volunteer was a $25 \mathrm{yr}$ old male with Hodgkin's disease in remission whose infusion studies were done in the outpatient department of the Clinical Center.

\section{Study protocol}

Nasal secretion, serum, and 24-hr urine specimens were collected daily from each volunteer and processed as described below. After an appropriate control period, $50 \mu \mathrm{c}$ of one of three labeled $\operatorname{IgA}$ preparations and $50 \mu \mathrm{c}$ of human serum albumin labeled with a different isotope were given intravenously from a calibrated syringe; a serum sample was taken exactly $10 \mathrm{~min}$ later for use in calculation of the initial serum value of radioactivity for each of the isotopes given. The rate of plasma clearance and extent of appearance of the isotopic proteins in nasal secretions were determined by measurement of the specific activity of the $\operatorname{IgA}$ and albumin in the serial serum and nasal secretion specimens. Stool samples were collected on day 3 of the study to be certain that no loss of radioactivity occurred into the gastrointestinal tract. Starting $48 \mathrm{hr}$ before isotope administration, we gave volunteers 10 drops of Lugol's solution three times daily throughout the study.

\section{Collection and processing of specimens}

Nasal secretions. Just before breakfast, $5 \mathrm{ml}$ sterile lactated Ringer's solution was pipetted into each nostril while the neck was hyperextended. The volunteer then leaned forward and blew the secretions from his nose, one nostril at a time, into a beaker. $10 \mathrm{~min}$ later, the process was repeated and secretions were pooled, homogenized in a glass tissue grinder on ice, and centrifuged at $1400 \mathrm{~g}$ at $4^{\circ} \mathrm{C}$ for $2 \mathrm{hr}$. Approximately $15 \mathrm{ml}$ of clear supernatant was placed in cellulose dialysis tubing 1 and concentrated 10 -fold by either of two methods, ultrafiltration at $140 \mathrm{~mm} \mathrm{Hg}$ at $4^{\circ} \mathrm{C}$ or by packing the casings in dry Sephadex G-200 for about $2 \mathrm{hr}$ at room temperature. The concentrates were dialyzed in the same casings for $24 \mathrm{hr}$ against two changes of 200 volumes of phosphate buffered saline, $\mathrm{pH} 7.0$, to remove unbound radioactivity

1 Size 8 ( 0.002 inch thick by 0.39 inch flat width), Union Carbide Corporation, Food Products Division, Chicago, Ill. (which was found to be negligible). The casings were opened, the volumes were recorded, and exactly $1 \mathrm{ml}$ was transferred to a sample bottle 2 for radioactivity counting. The remainder, about $0.5 \mathrm{ml}$, was kept separately in a $1 \mathrm{dr}$ screw-top vial for protein determinations, and both of these concentrates were kept at $-70^{\circ} \mathrm{C}$.

Serum. Blood was collected under sterile precautions, allowed to clot, and centrifuged. Exactly $1 \mathrm{ml}$ of serum was transferred to a sample bottle ${ }^{2}$ for measurement of radioactivity, and the remainder was kept separately for protein determinations. Specimens were kept at $-70^{\circ} \mathrm{C}$ unless otherwise indicated.

Urine. 24-hr urine samples were refrigerated during the collection period. After the volume was measured, exactly $4 \mathrm{ml}$ of urine sample was placed in a sample bottle $^{2}$ for measurement of radioactivity and kept at $-70^{\circ} \mathrm{C}$.

\section{Immunologic procedures}

Immunoglobulin and protein concentrations. A method of radial single diffusion in agar was used as described previously $(4,11)$. Monospecific antisera employed in agar plates were $(a)$ goat anti-human $\gamma-\mathrm{A}$ globulin (1: 20) (lot GP 2-66) ${ }^{3}$ (b) goat anti-human albumin (1: 20) (lot GP 1064F) ; ${ }^{3}$ and (c) rabbit anti-human IgG $(1: 40)$, made specific by absorption with fractions of normal serum prepared by gel filtration which contained $\operatorname{IgM}$ and IgA but lacked IgG. Total protein was measured by the biuret reaction or by nesslerization (12).

Immunoprecipitation procedure. To measure the amount of serum radioactivity present in a specific protein component, the following immunoprecipitin method was used. A measured amount of the radioactive serum specimen to be absorbed was placed in a $12 \times 75 \mathrm{~mm}$ conical centrifuge tube which in turn would just fit into a sample bottle, ${ }^{2}$ and an optimal amount (by prior determination) of specific antiserum was added at equivalence. The mixture was incubated at $37^{\circ} \mathrm{C}$ for $20 \mathrm{~min}$ and at $4^{\circ} \mathrm{C}$ overnight and then centrifuged. The precipitate was washed once in 10 volumes of saline and recentrifuged. The original and wash supernatants were combined and added to another $12 \times 75 \mathrm{~mm}$ conical tube. Saline was added to the tube containing the precipitate to bring both tubes to equal volumes. Radioactivity in each tube was determined and the per cent of radioactivity in the precipitate calculated.

Immunoelectrophoresis and radioimmunoelectrophoresis. Immuno- and radioimmunoelectrophoreses were performed as described previously $(2,13)$. Before electrophoresis of chromatographic fractions of serum or nasal secretion containing only small amounts of radioactive protein, we added nonlabeled serum or nasal secretion as carrier protein.

Gel filtration chromatography. A previously described method was used (5). For fractionation of serum and pooled nasal secretion specimens, a $2.5 \times 100 \mathrm{~cm}$ column was used. Fractionations of single nasal secretion speci-

\footnotetext{
2 Nuclear-Chicago Corporation, Des Plaines, Ill.

3 Hyland Laboratories, Los Angeles, Calif.
} 


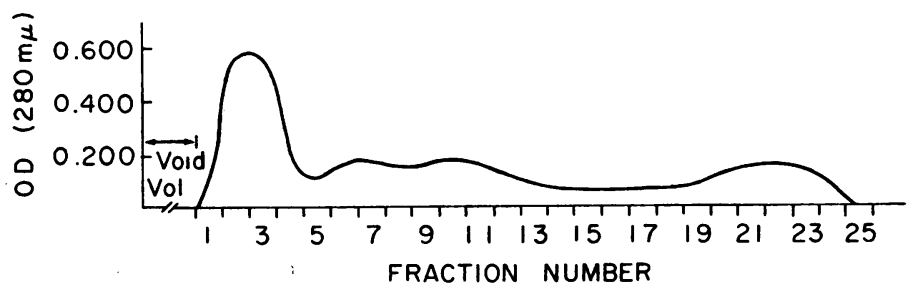

ULTRACENTRIFUGATION IN SUCROSE DENSITY GRADIENTS

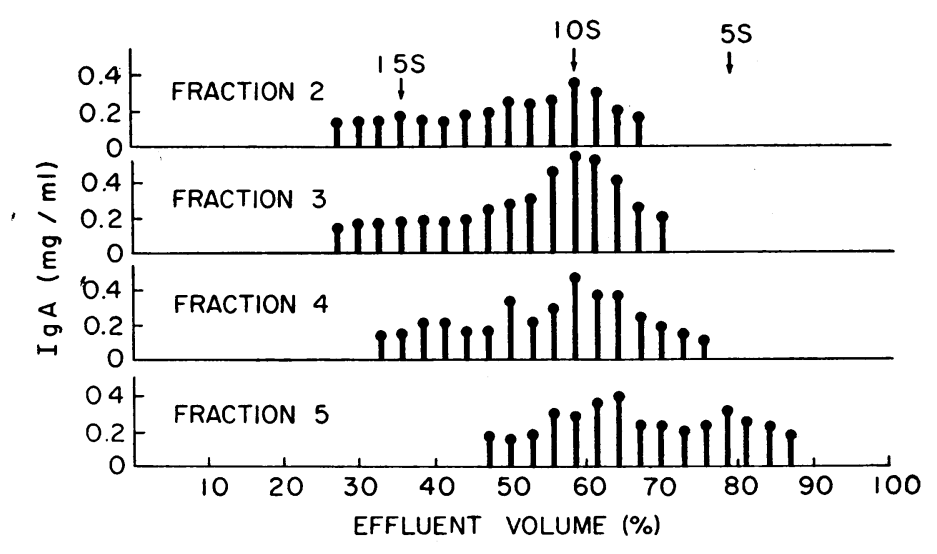

Fig. 1. Gel Filtration of $10 \mathrm{ML}$ OF POOLED AND CONCENTRATEd NASAL SeCretion on SePhadex G-200 (UPPER PaNel). The volume of each fraction was approximately $13 \mathrm{ml}$. The lower panel shows results of ultracentrifugational studies of four of the fractions from the gel filtration study in the upper panel. The fractions were concentrated 15 -fold before layering on the gradients.

mens were done on a $1.5 \times 30 \mathrm{~cm}$ column. All elutions were done with $0.15 \mathrm{M} \mathrm{NaCl}$ buffered at $\mathrm{pH} 7.4$ with 0.01 M sodium phosphate.

Sucrose density gradient ultracentrifugation. We performed studies using $5 \mathrm{ml}$ gradients of $5-20 \%$ sucrose by previously described methods (11).

Analytical ultracentrifugation. We performed studies using a Beckman model $\mathrm{E}$ analytic ultracentrifuge at $59,780 \mathrm{rpm}$. Pictures were taken at 8 -min intervals and the observed sedimentation coefficients corrected to standard conditions of water and $20^{\circ} \mathrm{C}\left(s_{20,}\right)$.

\section{Isolation of IgA and albumin for labeling}

Nasal secretion $\operatorname{Ig} A$. This procedure is described in detail since interpretation of certain of the results depends on analysis of the elution pattern of nasal secretion IgA from Sephadex G-200. Nasal secretions were collected daily for 24 days from 14 volunteers. On any given day the secretions from all the volunteers were combined, concentrated by ultrafiltration, and kept at $-70^{\circ} \mathrm{C}$ in one large pool. Eight charges of $10-\mathrm{ml}$ each of these pooled concentrated nasal secretions were applied separately to a column of Sephadex G-200. The elution pattern of the first charge (Fig. 1) and subsequent charges were similar to those previously described (5). $85 \%$ of the $\operatorname{IgA}$ was eluted in fractions $1-4$ and the re- mainder in fractions 5-8. Corresponding fractions eluted after each charge were pooled and concentrated.

Virtually all the protein present in fractions 1-4 was IgA (Table I). In immunoelectrophoresis against antiwhole human serum, these fractions also contained traces of an unidentified $\beta$-globulin. Fraction 5 contained IgA, $\mathrm{IgG}$, and an unidentified globulin. When $11 \mathrm{~S}$ IgA was used as the reference standard in the agar diffusion test, the $\operatorname{IgA}$ concentration in fraction 5 was calculated to be three-fold greater than the total protein content. Therefore, a serum IgA standard was used to calculate the

TABLE I

Data on protein components of fractionated nasal secretions

\begin{tabular}{|c|c|c|c|c|}
\hline \multirow{2}{*}{$\begin{array}{c}\text { Frac- } \\
\text { tion } \\
\text { No. }\end{array}$} & \multicolumn{2}{|c|}{ Total protein } & \multirow[b]{2}{*}{ IgA } & \multirow{2}{*}{$\begin{array}{l}\text { Sedimentation } \\
\text { behavior of } \\
\text { major protein } \\
\text { components }\end{array}$} \\
\hline & Biuret & Nessler & & \\
\hline & \multicolumn{2}{|c|}{$m g / m l$} & $m g / m l$ & $s_{20 . w}$ \\
\hline $\begin{array}{l}2 \\
3 \\
4 \\
5\end{array}$ & $\begin{array}{l}2.4 \\
3.0 \\
2.6 \\
1.2\end{array}$ & $\begin{array}{l}2.4 \\
3.4 \\
2.7 \\
1.3\end{array}$ & $\begin{array}{l}2.3^{*} \\
3.2^{*} \\
2.7^{*} \\
0.6 \ddagger\end{array}$ & $\begin{array}{l}11.52 \\
11.68 \\
11.56 \\
11.26,6.98\end{array}$ \\
\hline
\end{tabular}

* Reference standard, nasal secretion IgA.

$\ddagger$ Reference standard, normal serum IgA. 
IgA value for fraction 5, which was in accord with sedimentation studies.

By sucrose density gradient ultracentrifugation, fractions 1-4 contained a major component of IgA sedimenting near $10 \mathrm{~S}$ (Fig. 1, bottom panels). In fraction 5 there were two major components, $5 \mathrm{~S}$ and $9 \mathrm{~S}$, each of which had a similar sedimentation behavior after isolation and recentrifugation. IgA in fractions 6-8 sedimented predominantly in the $6 \mathrm{~S}$ region. In analytical ultracentrifugational studies, the major IgA component in fractions 2-5 had an $s_{20, w}$ value between 11.26 and 11.68 (Table I). In fraction 5 a second component sedimented at $6.98 \mathrm{~S}$. In addition to the slowly sedimenting $\operatorname{IgA}$, small amounts of IgG present in this fraction may also have sedimented at the slower rate.

In view of the above findings, the 8-12 $\mathrm{S}$ region of fraction 3 (Fig. 1) was labeled with ${ }^{125} \mathrm{I}$ as described below. This nasal secretion IgA preparation was also used as an antigen in sheep to prepare anti-nasal secretion $\operatorname{IgA}$. Five intramuscular injections were given at 3-wk intervals, the first one contained $0.25 \mathrm{mg}$ of $\operatorname{IgA}$ in Freund's complete adjuvant and the remaining ones contained $0.13 \mathrm{mg}$ of $\operatorname{IgA}$ in Freund's incomplete adjuvant. The sheep were bled 2 wk after the final injection of antigen.

To prepare an antiserum specific for the extra antigenic determinants in the $11 \mathrm{~S} \operatorname{IgA}$ for use in absorption studies, we absorbed a portion of the sheep anti-nasal secretion IgA antiserum with purified $7 \mathrm{~S}$ A myeloma protein until no further precipitate formed.

Autologous serum $\operatorname{Ig} A(7 \mathrm{~S})$. Immediately after centrifugation of freshly clotted blood from two volunteers, $10 \mathrm{ml}$ of serum from each was fractionated separately on columns of Sephadex G-200. All fractions containing IgA were placed in dialysis casing, dialyzed against $0.005 \mathrm{~m}$ phosphate buffer ( $\mathrm{pH} 6.4$ ) to preferentially precipitate proteins not soluble in buffer of low ionic strength, and the supernatant concentrated by ultrafiltration. By this method, both preparations contained about $20 \%$ IgA by weight. They were not further purified in order to avoid damage to the protein and loss of representative $\operatorname{IgA}$ molecules.

Honologous serum $\operatorname{IgA}(7 S)$ and human serum albumin. These sera were prepared as previously described (14). The $\operatorname{IgA}$ was obtained from the plasma of a patient with a longstanding elevated serum level of $\operatorname{IgA}$ but who was otherwise healthy. The albumin was obtained from normal serum. Both protein preparations were isolated by block electrophoresis, which was carried out for $18 \mathrm{hr}$ in $\mathrm{pH} 8.6$ sodium barbital buffer with supporting medium of polyvinyl chloride particles and polyvinyl chloride-polyvinylacetate copolymer. Both preparations were immunologically pure based on studies of double diffusion in agar and radioimmunoelectrophoresis. The mean plasma survival time $\left(t_{i}\right)$ of both preparations, 6.1 days for $\operatorname{Ig} \mathrm{A}$ and 17 days for albumin, was normal.

Protein labeling and radioactivity measurements. All preparations were labeled with either ${ }^{181} \mathrm{I}$ or ${ }^{120} \mathrm{I}$ by the iodine monochloride technique of McFarlane (15). Normal serum albumin was added to each preparation to a final concentration of $35 \mathrm{mg} / \mathrm{ml}$ to prevent protein damage by self-irradiation, and the mixture was sterilized by filtration. Before injection into volunteers, all materials were passed through a Millipore filter (Millipore Filter Corp., Bedford, Mass.) and safety tested for sterility and for lack of pyrogenicity in rabbits. Specimens were counted along with appropriate standards in a dualchannel, automatic gamma-counting system with a 3 inch crystal.4 When ${ }^{125} \mathrm{I}$ was counted in the presence of ${ }^{131} \mathrm{I}$, the count rate which appeared in the ${ }^{125} \mathrm{I}$ channel was appropriately corrected for the presence of ${ }^{131} \mathrm{I}$ counts. To avoid the need to correct for isotopic decay, all specimens were counted at the end of each study. Calculations were done as previously described (14). All reported measurements have been corrected for background.

The specific activity of a given protein was calculated by dividing the radioactivity of the protein $(\mathrm{cpm} / \mathrm{ml})$ as determined by the immunoprecipitin method by the concentration of the protein $(\mathrm{mg} / \mathrm{ml})$ as measured by radial single diffusion in agar.

\section{Results}

Plasma clearance and appearance in nasal secretions of intravenously injected nasal secretion $\operatorname{Ig} A(8-12 S)$

Characterization and turnover of ${ }^{125}$ I-labeled nasal secretion $\operatorname{Ig} A$. By radioimmunoelectrophoresis, only the IgA line contained radioactivity when carrier whole nasal secretion containing ${ }^{125} \mathrm{I}$-labeled nasal secretion $\operatorname{IgA}$ was tested against antiwhole human serum. Most of the labeled nasal secretion IgA sedimented by sucrose density gradient ultracentrifugation between 8 and $15 \mathrm{~S}$ which closely paralleled the sedimentation behavior of unlabeled nasal secretion IgA obtained from fraction 3 (Fig. 1) that was added as an internal marker. $95 \%$ of the radioactivity in the fraction collected at the $10 \mathrm{~S}$ level of the gradient was precipitated by the antiserum specific for the extra antigenic determinants of nasal secretion IgA.

Four volunteers received about $0.25 \mathrm{mg}$ of nasal secretion IgA intravenously which contained $50 \mu \mathrm{c}$ of ${ }^{125} \mathrm{I}$. Along with this was given $50 \mu \mathrm{c}$ of ${ }^{131} \mathrm{I}$ labeled human serum albumin, for control purposes. The $\operatorname{IgA}$ was rapidly cleared so that within 4 days less than $5 \%$ of the initial dose remained in the serum and less than $12 \%$ in the body (Fig. 2). We performed ultracentrifugational studies on the sera of two of the volunteers $6 \mathrm{hr}$ after injection of the labeled IgA. The studies showed that although one-half of the ${ }^{125} \mathrm{I}$-labeled IgA sedimented in the

\footnotetext{
4 Model 4222, Nuclear-Chicago Corporation, Des Plaines, Ill.
} 
$11 \mathrm{~S}$ region, the remaining portion sedimented rapidly at the bottom of the tube, possibly representing aggregation. The ${ }^{131}$ I-labeled albumin sedimented in normal fashion which was consistent with its normal survival time (14).

Appearance in nasal secretions of intravenouslyinjected nasal secretion IgA. Nasal secretions and sera were collected daily in the four volunteers after intravenous injection of a mixture of ${ }^{125} \mathrm{I}$-labeled nasal secretion IgA and ${ }^{131}$ I-labeled human serum albumin. The specific activity of albumin in nasal secretions was found at all times to be the same as its specific activity in simultaneously collected sera. This indicated that the techniques of collecting and processing nasal secretion samples were satisfactory and that the serum albumin pool was the source of albumin in the nasal secretions.

The specific activity of ${ }^{125}$ I-labeled material in whole nasal secretions of each volunteer, however, was less than $10 \%$ of that in serum for 2 wk after the injection. To analyze this further, the nasal secretions collected from all four volunteers $48 \mathrm{hr}$ after injection were pooled, concentrated, and studied by ultracentrifugation in a sucrose density gradient. The pools were necessary to obtain significant levels of radioactivity in individual gradient fractions. After ultracentrifugation, fractions between 35 and $65 \%$ effluent volume (the IgAcontaining fractions) were pooled and analyzed for specific activity of IgA. The specific activity of $\operatorname{IgA}$ in this pool was $1.7 \mathrm{cpm} / \mathrm{mg}$, which was $1.7 \%$ of the simultaneously determined specific activity $(99 \mathrm{cpm} / \mathrm{mg}$ ) of $\mathrm{IgA}$ in a corresponding serum pool, suggesting that despite rapid clearance from plasma only a very small amount of injected nasal secretion IgA appeared in nasal secretions, possibly by passive diffusion alone.

\section{Appearance in nasal secretions of intravenously injected serum 7 S IgA preparations.}

Homologous serum $7 S I g A$. Approximately $0.5 \mathrm{mg}$ of a purified preparation of serum $\operatorname{IgA}$ containing $50 \mu \mathrm{C}$ of ${ }^{131} \mathrm{I}$ was injected intravenously into one volunteer, and 3 days later, nasal secretions were collected and concentrated for study. The specific activity of $\operatorname{IgA}$ in the whole nasal secretion specimen was $12 \mathrm{cpm} / \mathrm{mg}$, which was $3.4 \%$ of the specific activity of IgA in whole serum at the same time $(353 \mathrm{cpm} / \mathrm{mg})$. Studies done by

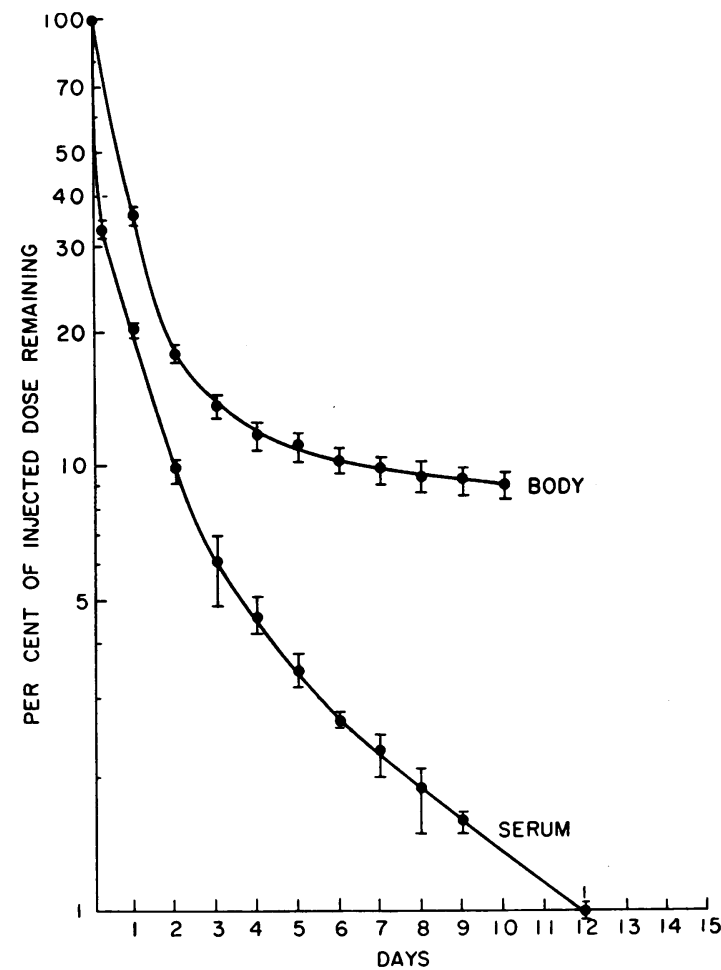

FIG. 2. NASAL SECRETION $11 \mathrm{~S}$ IgA-100 I DISAPPEARANCE CURVES. Vertical brackets show range of values of the four volunteers.

ultracentrifugation in sucrose density gradients (Fig. 3) revealed that the labeled $\operatorname{IgA}$ in both nasal secretions and serum sedimented in the $7 \mathrm{~S}$ region. These studies suggested, therefore, that IgA can be transferred from serum into nasal secretions and that it is unaltered in sedimentation behavior. The 30 -fold drop in specific activity between serum and nasal secretions was not so striking, however, when only the $7 \mathrm{~S}$ portion of the sucrose density gradient was examined. In this case the specific activity of $\operatorname{IgA}, 195 \mathrm{cpm} / \mathrm{mg}$, was $42 \%$ of the specific activity of $\operatorname{IgA}$ in serum, $463 \mathrm{cpm} / \mathrm{mg}$. No radioactivity was detected in the $11 \mathrm{~S}$ region of the sucrose density gradient containing the nasal secretion specimen, which suggested that the ${ }^{131}$ I-labeled serum IgA was not incorporated into nasal secretion $11 \mathrm{~S}$ IgA.

Autologous serum $7 S I g A$. Two volunteers were injected with labeled fractions of their own serum which contained IgA. Results were similar in both volunteers; therefore, only one will be described in detail. 

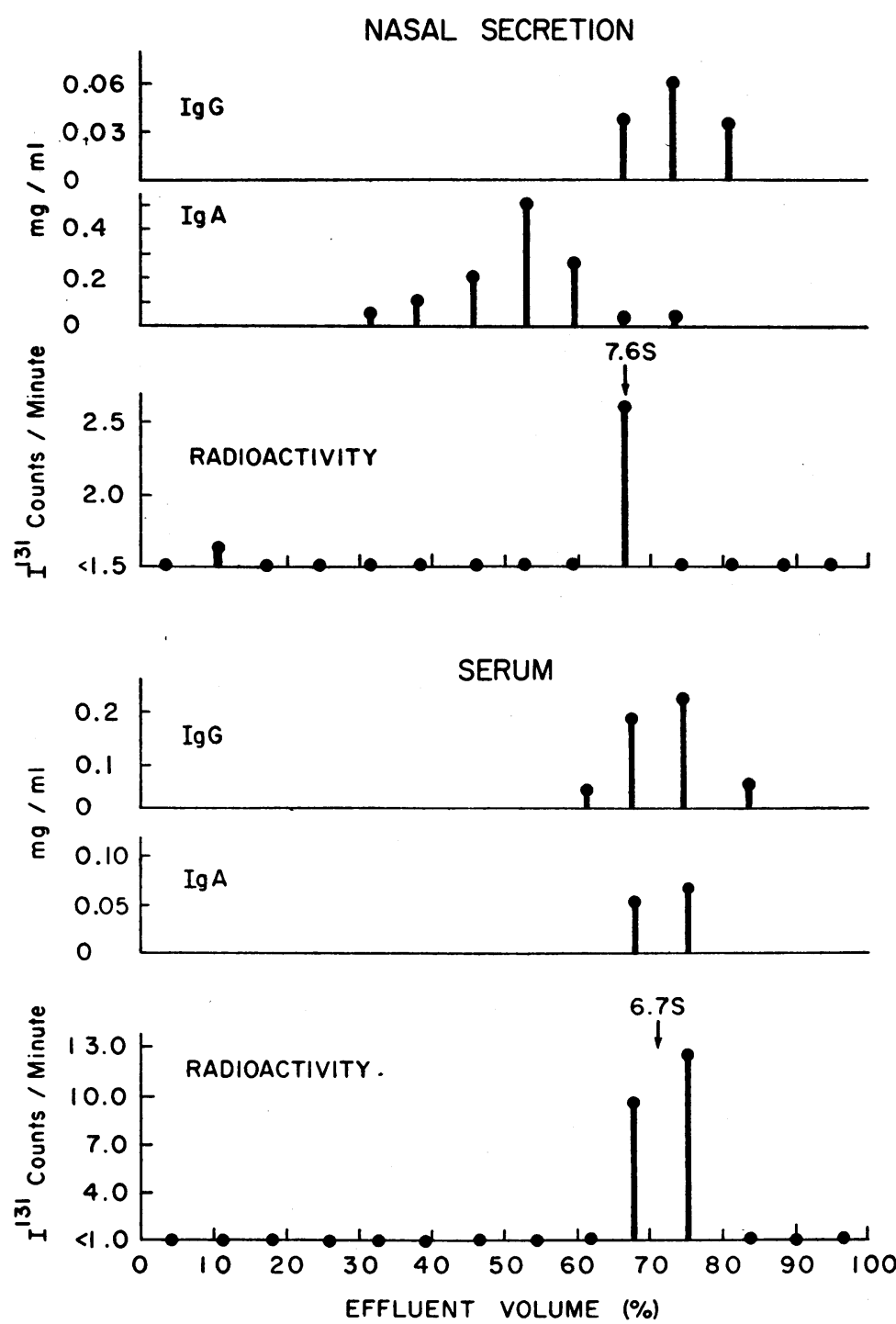

Fig. 3. Sedimentation BeHaVior of ${ }^{18 I}$ I-LAbeled $7 \mathrm{~S}$ Homologous IgA IN SERUM AND NASAL SECRETIONS 3 DAYS AFTER INTRAVENOUS INJECTION. Each sucrose density gradient fraction contained about $0.35 \mathrm{ml}$.

1. Characterization of ${ }^{181}$ I-labeled autoloGOUS SERUM.

(a) Radioimmunoelectrophoresis. Six separate proteins were shown to be labeled. They were $\operatorname{IgA}, \operatorname{IgG}$, albumin, and three unidentified $\alpha$ - and $\beta$-migrating proteins.

(b) Sucrose density gradient ultracentrifugation. The distribution of radioactivity in a serum specimen taken $48 \mathrm{hr}$ after injection of the labeled autologous serum preparation is shown in the bottom panel of Fig. 4. The predominate radioactivity sedimented at $6.6 \mathrm{~S}$, which corresponded pre- cisely with the highest concentrations of both $\operatorname{IgA}$ and IgG; together they accounted for $66 \%$ of the serum radioactivity as determined by immunoprecipitation. A smaller peak of radioactivity occurred in the $17 \mathrm{~S}$ region. This labeled protein was unidentified; no label was detected on IgM in radioimmunoelectrophoresis.

(c) Stability of labeled IgA after injection of autologous serum fraction. The plasma clearance of total radioactivity approximated that normally seen for IgG (14), which was the major labeled component of the injected serum. The rate of 

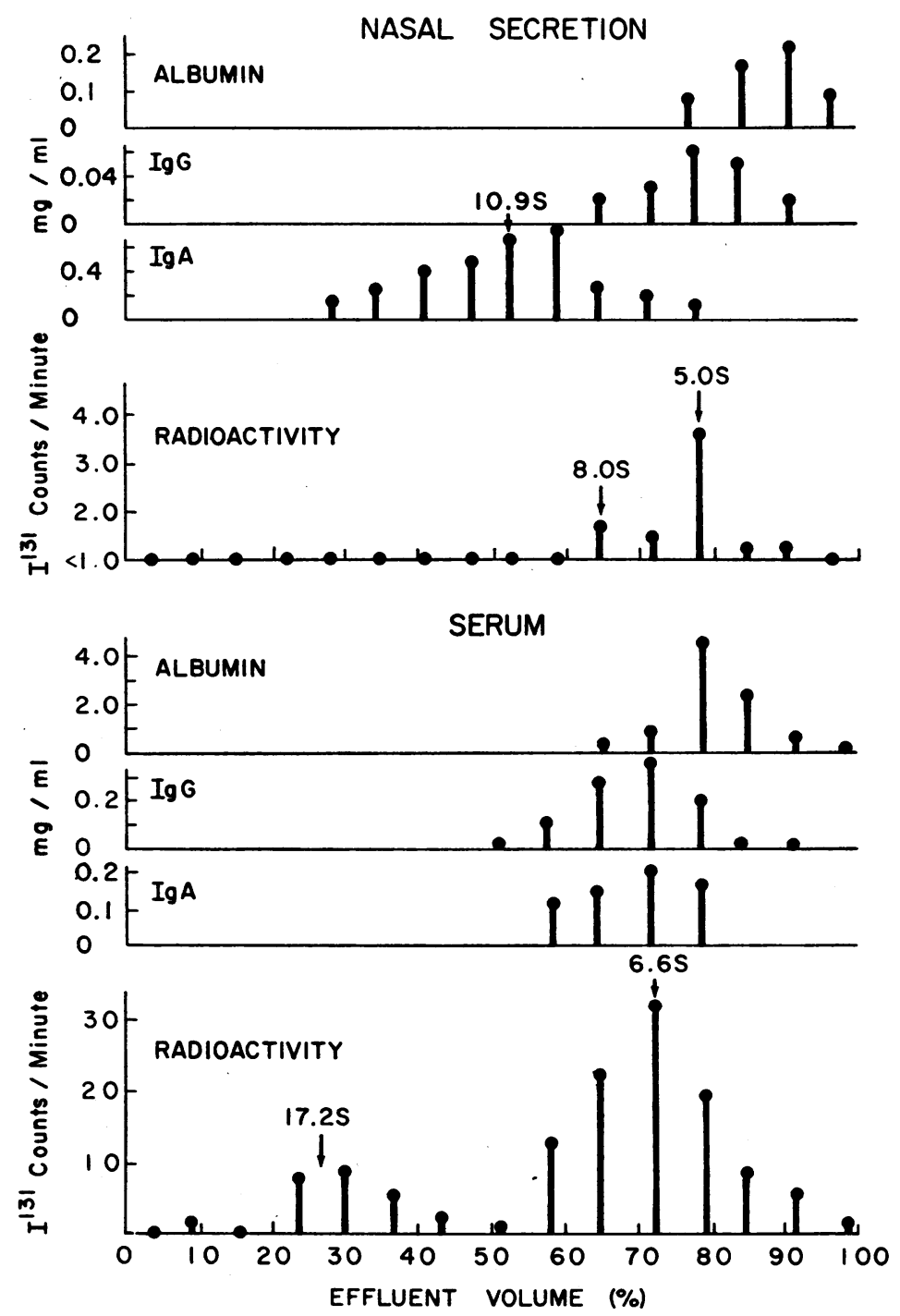

Fig. 4. Distribution OF RADIOACTIVITY DURING ULTRACENTRIFUgation OF SERUM AND NASAL SECRETIONS AFTER INJECTION OF LABELED AUTOLOGOUS SERUM PREPARATION CONTAINING 20\% IGA BY WEIGHT. Nasal secretions for 3 days after the injection were pooled and concentrated; serum was taken 2 days after the injection. Each gradient fraction contained about $0.35 \mathrm{ml}$.

plasma clearance of $\operatorname{IgA}$, based on immunoprecipitation with antiserum specific for the heavy chain of $\operatorname{IgA}$, was also within the normal range (16).

2. Appearance of radioactivity in Nasal SECRETIONS.

(a) Specific activity of IgA in whole nasal secretions. From Table II, it can be seen that the maximum possible specific activity of IgA in nasal secretions was from 4.3 to $10.2 \%$ of that present in the serum, and that there was no trend toward in- creasing values which might have suggested a lag phase in incorporation of labeled proteins into nasal secretions.

(b) Gel filtration studies. Nasal secretions collected for 3 consecutive days after injection of the labeled serum were pooled and concentrated. A portion of this pool was applied to a small column of Sephadex G-200 (Fig. 5). Elution revealed three peaks by optical density tracing; the second peak did not show the characteristic double hump 
TABLE II

Specific activity of $\operatorname{IgA}$ in nasal secretions and serum after injection of labeled autologous serum

\begin{tabular}{|c|c|c|c|c|}
\hline \multirow[b]{2}{*}{$\begin{array}{l}\text { Days after } \\
\text { injection } \\
\text { of labeled } \\
\text { serum }\end{array}$} & \multicolumn{4}{|c|}{ Serum } \\
\hline & $\begin{array}{c}\text { Radio- } \\
\text { activity } \\
\text { due to } \\
\text { IgA* }\end{array}$ & $\begin{array}{c}\text { Concen- } \\
\text { tration } \\
\text { of IgA }\end{array}$ & $\underset{\mathrm{S}}{\text { Specif }}$ & $\begin{array}{l}\text { ific activity } \\
\text { of IgA }\end{array}$ \\
\hline \multirow[t]{3}{*}{$\begin{array}{l}1 \\
2 \\
3 \\
5\end{array}$} & $\begin{array}{c}c p m / m l \\
2187 \\
1756 \\
1338 \\
958\end{array}$ & $\begin{array}{c}m g / m l \\
2.9 \\
2.9 \\
2.9 \\
2.9\end{array}$ & $c_{1}$ & $\begin{array}{l}p m / m g \\
754 \\
606 \\
461 \\
330\end{array}$ \\
\hline & \multicolumn{4}{|c|}{ Nasal secretions } \\
\hline & $\begin{array}{c}\text { Total } \\
\text { radio- } \\
\text { activity } \ddagger\end{array}$ & $\begin{array}{l}\text { Concen- } \\
\text { tration } \\
\text { of IgA }\end{array}$ & $\begin{array}{c}\text { Speci } \\
\text { of IgA, } \\
\text { ma }\end{array}$ & $\begin{array}{l}\text { ific activity } \\
\text { theoretical } \\
\text { aximum } \S\end{array}$ \\
\hline & $c p m / m l$ & $m g / m l$ & $c p m / m g$ & $\begin{array}{l}\text { \% of } \\
\text { serum value }\end{array}$ \\
\hline $\begin{array}{l}1 \\
2 \\
3 \\
5\end{array}$ & $\begin{array}{r}24 \\
26 \\
6 \\
5\end{array}$ & $\begin{array}{l}0.39 \\
0.42 \\
0.31 \\
0.26\end{array}$ & $\begin{array}{l}62 \\
62 \\
20 \\
19\end{array}$ & $\begin{array}{r}(8.2) \\
(10.2) \\
(4.3) \\
(5.8)\end{array}$ \\
\hline
\end{tabular}

* Calculated on basis of whole serum radioactivity times per cent of label precipitated by anti-IgA.

$\ddagger$ Portion of this radioactivity due to IgA not determined; if radioactivity in secretion assumed same distribution as in serum, then only $20 \%$ of this value would be due to IgA and specific activity of IgA would be correspondingly lower.

$\S$ For purposes of calculation, all radioactivity assumed to be on IgA.

(see Fig. 1) seen when secretions were processed in larger columns. The peak of radioactivity was in pool 7, where $7 \mathrm{~S} \mathrm{IgA} \mathrm{and} 7 \mathrm{~S} \mathrm{IgG} \mathrm{were} \mathrm{in}$ highest concentration. Pools 4 and 5 contained the bulk and nearly equal amounts of $11 \mathrm{~S} \operatorname{IgA}$, yet radioactivity was detected only in pool 5 . Therefore, it was presumed that this radioactivity was not attached to $11 \mathrm{~S} \operatorname{IgA}$ but probably represented the labeled protein in nasal secretions with $8 \mathrm{~S}$ sedimentation behavior (Fig. 4). Its identity could not be established by radioimmunoelectrophoresis because of the low intensity of radioactivity in pool 5.

Even if the radioactivity in pool 5 were present on $\operatorname{IgA}$, the specific activity of $\operatorname{IgA}$ in pool 5 (1.2 $\mathrm{cpm} / \mathrm{mg}$ ) would have been less than one-half of $1 \%$ of that in the serum $(280 \mathrm{cpm} / \mathrm{mg})$ counted simultaneously. This indicates that essentially none of the $7 \mathrm{~S}$ autologous serum $\operatorname{IgA}$ was incorporated in vivo into $11 \mathrm{~S}$ nasal secretion IgA.

(c) Sedimentation studies. Another portion of the pooled nasal secretions was studied by ultracentrifugation in a sucrose density gradient (Fig. 4, top panel). Radioactivity was detected predominantly in the 5-8 S region of the gradient. No radioactivity was detected in the $11 \mathrm{~S}$ region of the gradient which contained the bulk of IgA. Therefore, these studies confirmed the above gel filtration studies and demonstrated that although small amounts of autologous $7 \mathrm{~S}$ sedimenting proteins were transferred into nasal secretions from plasma, they were not incorporated into $11 \mathrm{~S}$ nasal secretion $\operatorname{IgA}$.

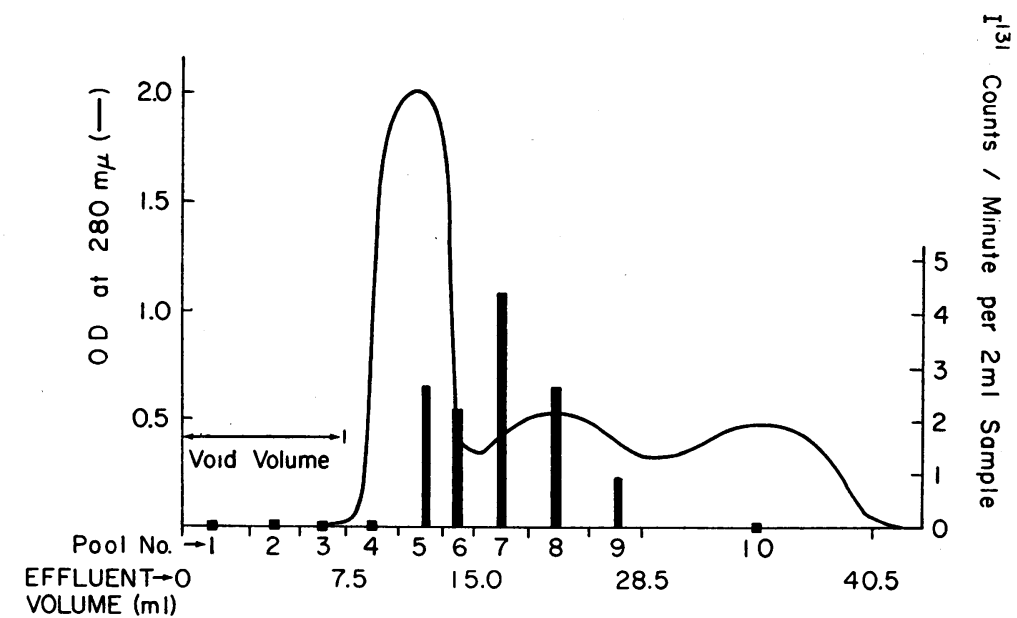

Fig. 5. Gel filtration on Sephadex G-200 of nasal secretions colLECTED AND POOLED FOR 3 DAYS AFTER INJECTION OF ${ }^{181}$ I-LABELED AUTOLOGOUS SERUM PREPARATION CONTAINING $20 \%$ IgA BY WEIGHT. 


\section{Discussion}

Nasal secretions contain two components of $\operatorname{IgA}$, one of molecular size comparable to the $7 \mathrm{~S} \operatorname{IgA}$ in serum and a larger and more abundant component comprising about $80 \%$ of the $\operatorname{IgA}$ with predominantly $11 \mathrm{~S}$ sedimentation behavior (11). The latter component contains antigenic determinants in addition to those found on IgA of serum origin (5). The present experiments were designed to investigate mechanisms of appearance of both $\operatorname{IgA}$ components in nasal secretions.

It was shown that after intravenous administration, $7 \mathrm{~S} \mathrm{IgA} \mathrm{appears} \mathrm{in} \mathrm{nasal} \mathrm{secretions} \mathrm{and} \mathrm{is}$ unchanged in sedimentation behavior. The mechanism of its transfer into the secretions is unknown. At least 12 serum protein components, including $\operatorname{Ig} \mathrm{A}$, have been identified in nasal washings from normal volunteers (4), and although a specific transport mechanism could exist for each, it is more reasonable to assume that most accumulate in nasal secretions as a result of passive diffusion from the vascular supply of the nasal mucosa. Consistent with this hypothesis is the finding in nasal secretions during viral respiratory illness of an increased frequency of the same serum components (2).

Although a substantial part of the $7 \mathrm{~S} \operatorname{IgA}$ in nasal secretions was shown to originate from serum, data from experiments in the volunteer who received an intravenous injection of a purified preparation of $7 \mathrm{~S} \mathrm{IgA} \mathrm{suggested} \mathrm{that} \mathrm{some} 7 \mathrm{~S}$ IgA may be produced locally in tissues lining the respiratory tract. Whereas the specific activity of $\operatorname{IgA}$ in nasal secretions was $3.4 \%$ of that in serum, the specific activity of only the $7 \mathrm{~S}$ portion of IgA in nasal secretions was slightly less than one-half of that seen in serum. Additional data is needed to confirm this latter finding since only a limited number of specimens were studied. Nevertheless, local production of $7 \mathrm{~S}$ IgA would be consistent with the recent finding that $7 \mathrm{~S} \mathrm{IgG}$ also appears to be synthesized locally in respiratory tissues. ${ }^{5}$ Also, one could not rule out the additional possibility that some of the $7 \mathrm{~S}$ IgA may arise from dissociation of the $11 \mathrm{~S} \mathrm{IgA.}$

5 Butler, W. T., T. A. Waldmann, R. D. Rossen, R. G. Douglas, Jr., and R. B. Couch. Changes in immunoglobulins in nasal secretion during viral respiratory infection. In manuscript.
To explain the presence of $11 \mathrm{~S}$ IgA in nasal secretions, three possibilities were considered: $(a)$ rapid selective secretion of low levels of circulating $11 \mathrm{~S} \operatorname{IgA} ;(b)$ incorporation of $7 \mathrm{~S}$ serum IgA into the $11 \mathrm{~S} \operatorname{IgA}$ molecule during passage of the former through the tissues of the respiratory tract; and (c) synthesis of the entire $11 \mathrm{~S} \operatorname{IgA}$ molecule de novo in the tissues of the respiratory tract. On the basis of the present experiments, the first possibility appears unlikely, since labeled $11 \mathrm{~S} \mathrm{IgA} \mathrm{isolated} \mathrm{from} \mathrm{nasal} \mathrm{secretions} \mathrm{was} \mathrm{not}$ transferred after intravenous injection into nasal secretions despite rapid clearance from the plasma. A stable form of $11 \mathrm{~S} \mathrm{IgA}$ thought to represent a polymer of $7 \mathrm{~S} \mathrm{IgA} \mathrm{has} \mathrm{been} \mathrm{demonstrated} \mathrm{in}$ the plasma of some individuals, although it has been shown not to contain the extra antigenic determinants characteristic of nasal secretion $11 \mathrm{~S}$ IgA (11). In a previous study it was also shown that the IgA polymers in serum do not always contain antibody activity, when at the same time antibody activity is present in $11 \mathrm{~S} \operatorname{IgA}$ in nasal secretions (7).

The second possibility is also untenable on the basis of the present experiments. After intravenous injection of labeled serum $7 \mathrm{~S} \operatorname{IgA}$ into three volunteers, no radioactivity was incorporated into nasal secretion $\operatorname{IgA}$ sedimenting in the 9-13 S regions. Since in the presence of a negative experiment it could be argued that a homologous preparation of IgA might be handled abnormally by the body, two of these volunteers received labeled $7 \mathrm{~S} \mathrm{IgA}$ from their own sera. These autologous preparations contained about $20 \% \operatorname{IgA}$ by weight. No attempt was made to further purify this material in order to avoid alteration of the protein and to avoid selection of IgA molecules not representative of those present in whole serum. Results suggested, however, that these labeled $7 \mathrm{~S}$ IgA preparations were technically satisfactory, since they had normal rates of plasma clearance after intravenous injection.

On the basis of these findings, therefore, the most probable mechanism to explain the secretion of $11 \mathrm{~S} \operatorname{IgA}$ in nasal secretions is that of the third possibility, local synthesis. Consistent with this hypothesis would be $(a)$ the prolonged and sustained increase in $\operatorname{Ig} \mathrm{A}$ concentration in nasal secretions after viral illness, without a corresponding change in serum concentration of $\operatorname{IgA}(17) ;^{s}$ 
(b) the lack of consistent correlation between virus neutralizing titer in nasal secretions and the presence of IgA neutralizing antibody in the serum (7); and (c) results of immunofluorescent studies. By using fluorescein and rhodamine conjugated antisera specific for $7 \mathrm{~S} \operatorname{IgA}$ and for the distinctive extra antigenic determinants of secretory $11 \mathrm{~S}$ IgA, respectively, we found both antigenic components together in the cytoplasm of numerous cells in the nasal submucosa as well as in the perifollicular areas of palatine and pharyngeal tonsils and in the interstitial spaces of the submaxillary and parotid salivary glands (18). Some of the cells which contain both of the antigenic components resemble plasma cells (18).

The $11 \mathrm{~S} \operatorname{IgA}$ in nasal secretions may be similar to that seen in other respiratory secretions (19) and in other external secretions $(11,20)$. Recently, evidence has accumulated from several laboratories that salivary $\operatorname{IgA}$, at least in part, may be synthesized locally in the parotid gland (21-23). The $11 \mathrm{~S} \mathrm{IgA} \mathrm{of} \mathrm{colostrum} \mathrm{has} \mathrm{been}$ broken down into component fragments, one which is antigenically similar to serum $\operatorname{IgA}$ and the other which possesses the extra antigenic determinants characteristic of IgA from external secretions (24). The latter small-molecular-weight substance has been secreted by the parotid glands of patients who have an absence of detectable IgA in serum or saliva (25). We have also found the component containing the extra antigenic determinants in nasal secretions of an adult man who lacked $\operatorname{IgA}$ in serum and nasal secretion. ${ }^{8}$

Although the total protein concentrations in parotid saliva and nasal secretions are approximately equal in native secretions, it is interesting to observe that fewer serum protein components have been identified in parotid saliva. Ultracentrifugational study has shown $7 \mathrm{~S}$ components to be absent (26) ; this finding is in striking contrast to the more heterogeneous protein composition of nasal secretions (2). Tracer experiments confirm the latter differences. Tomasi and associates were unable to detect any transfer of labeled $7 \mathrm{~S}$ IgA or $7 \mathrm{~S} \mathrm{IgG} \mathrm{from} \mathrm{the} \mathrm{serum} \mathrm{into} \mathrm{saliva} \mathrm{(21),}$ and McFarlin and associates detected transfer of only minute amounts of $7 \mathrm{~S} \mathrm{IgA}$ in two of three cases studied and none in the third case (22). In contrast, isotopically labeled $7 \mathrm{~S} \mathrm{IgA,} \mathrm{as} \mathrm{shown} \mathrm{in}$

\footnotetext{
6 Unpublished data.
}

the present experiments, and $7 \mathrm{~S} \mathrm{IgG}{ }^{5}$ have been found in nasal secretions soon after intravenous injection. Thus, although the immunologic characteristics and the mechanism of appearance of $11 \mathrm{~S} \operatorname{IgA}$ may be similar in nasal secretions and saliva, the composition of the other protein components in these two external secretions are significantly different. This consideration must be taken into account in the interpretation of studies dealing with the mechanisms of appearance of antibody in different external secretions (27).

\section{Acknowledgments}

Gratitude is expressed to Dr. Wilton E. Vannier for performing analytical ultracentrifugational studies. We thank Mr. Myrl Alexander, Director, and Dr. Charles E. Smith, Chief Medical Officer, Bureau of Prisons, U. S. Department of Justice. The excellent cooperation of the volunteers is gratefully acknowledged.

\section{References}

1. Remington, J. S., K. L. Vosti, A. Lietze, and A. L. Zimmerman. 1964. Serum proteins and antibody activity in human nasal secretions. J. Clin. Invest. $43: 1613$.

2. Rossen, R. D., W. T. Butler, T. R. Cate, C. F. Szwed, and R. B. Couch. 1965. Protein composition of nasal secretion during respiratory virus infection. Proc. Soc. Exptl. Biol. Med. 119: 1169.

3. Bellanti, J. A., M. S. Artenstein, and E. L. Buescher. 1965. Characterization of virus neutralizing antibodies in human serum and nasal secretions. $J$. Immunol. 94 : 344.

4. Rossen, R. D., A. L. Schade, W. T. Butler, and J. A. Kasel. 1966. The proteins in nasal secretion: a longitudinal study of the $\gamma \mathrm{A}$-globulin, $\gamma \mathrm{G}$-globulin, albumin, siderophilin, and total protein concentrations in nasal washings from adult male volunteers. J. Clin. Invest. 45 : 768.

5. Rossen, R. D., R. H. Alford, W. T. Butler, and W. E. Vannier. 1966. The separation and characterization of proteins intrinsic to nasal secretion. J. Immunol. 97 : 369.

6. Artenstein, M. S., J. A. Bellanti, and E. L. Buescher. 1964. Identification of the antiviral substances in nasal secretions. Proc. Soc. Exptl. Biol Med. 117 : 558.

7. Rossen, R. D., R. G. Douglas, Jr., T. R. Cate, R. B. Couch, and W. T. Butler. 1966. The sedimentation behavior of rhinovirus neutralizing activity in nasal secretion and serum following the rhinovirus common cold. J. Immunol. 97 : 532.

8. Cate, T. R., R. D. Rossen, R. G. Douglas, Jr., W. T. Butler, and R. B. Couch. 1966. The role of nasal secretion and serum antibody in the rhinovirus common cold. Am. J. Epidemiol. 84: 352. 
9. Smith, C. B., R. H. Purcell, J. A. Bellanti, and R. M. Chanock. 1966. Protective effect of antibody to parainfluenza type 1 virus. New Engl. J. Med. 275 : 1145 .

10. Knight, V. 1964. The use of volunteers in medical virology. In Progress in Medical Virology. Karger, Basel, Switzerland. 6: 1.

11. Rossen, R. D., W. T. Butler, W. E. Vannier, R. G. Douglas, Jr., and A. G. Steinberg. 1966. The sedimentation and antigenic properties of proteins in nasal and other external secretions. J. Immunol. 97 : 925.

12. Kabat, E. A., and M. M. Mayer. 1961. Experimental Immunochemistry. Charles C Thomas, Publisher, Springfield.

13. Rossen, R. D., S. M. Wolff, W. T. Butler, and W. E. Vannier. 1967. The identification of low molecular weight flocculating antibodies in the serum of the rabbit, monkey and man. J. Immunol. $98: 764$.

14. Wochner, R. D., G. Drews, W. Strober, and T. A. Waldmann. 1966. Accelerated breakdown on immunoglobulin $\mathrm{G}$ ( $\mathrm{IgG}$ ) in myotonic dystrophy: a hereditary error of immunoglobulin catabolism. J. Clin. Invest. $45: 321$.

15. McFarlane, A. S. 1958. Efficient trace-labeling of proteins with iodine. Nature. 182: 53.

16. Solomon, A., and T. B. Tomasi, Jr. 1964. Metabolism of IgA $\left(\mathrm{B}_{2} \mathrm{~A}\right)$ globulin. Clin. Res. 12: 452.

17. Alford, R. H., R. D. Rossen, W. T. Butler, and J. A. Kasel. 1967. Neutralizing and hemagglutinationinhibiting activity of nasal secretions following experimental human infection with A2 influenza virus. J. Immunol. $98: 724$.

18. Rossen, R. D., C. Morgan, K. C. Hsu, and H. M. Rose. 1967. Localization of $11 \mathrm{~S}$ external secre- tory $\operatorname{IgA}$ globulin by immunofluorescence. Clin. Res. 15 : 298.

19. Masson, P. L., J. F. Heremans, and J. Prignot. 1965. Studies on the proteins of human bronchial secretions. Biochim. Biophys. Acta. 111: 466.

20. Chodirker, W. B., and T. B. Tomasi, Jr. 1963. Gamma-globulins : quantitative relationships in human serum and nonvascular fluids. Science. 142 : 1080.

21. Tomasi, T. B., Jr., E. M. Tan, A. Solomon, and R. A. Prendergast. 1965. Characteristics of an immune system common to certain external secretions. $J$. Exptl. Med. 121 : 101.

22. McFarlin, D. E., W. Strober, R. D. Wochner, T. A. Waldmann. 1965. Immunoglobulin A production in ataxia telangiectasia. Science. 150: 1175.

23. Stiehm, E. R., J. P. Vaerman, and H. H. Fudenberg. 1966. Plasma infusions in immunologic deficiency states: metabolic and therapeutic studies. Blood. 28: 918.

24. Hong, R., B. Pollara, and R. A. Good. 1966. A model for colostral IgA. Proc. Natl.Acad. Sci. 56: 602.

25. South, M. A., M. D. Cooper, F. A. Wollheim, R. Hong, and R. A. Good. 1966. The IgA system. I. Studies of the transport and immunochemistry of IgA in the saliva. J. Exptl. Med. 123: 615.

26. Tomasi, T. B., Jr., and S. Zigelbaum. 1963. The selective occurrence of $\gamma_{1} \mathrm{~A}$ globulins in certain body fluids. J. Clin. Invest. 42: 1552.

27. Douglas, R. G., Jr., R. D. Rossen, W. T. Butler, and R. B. Couch. 1967. Rhinovirus neutralizing activity in tears, parotid saliva, nasal secretions and serum. J. Immunol. 99 : 297.

\section{NOTICE TO SUBSCRIBERS}

Post Offices will not forward the Journal when you move.

Please notify The Journal of Clinical Investigation, The Rockefeller University Press, Box 261, New York, N. Y. 10021, when your address changes. Include your zip code number. 